\title{
The Analysis of Active Constraint of Equity Incentive in Listed Companies
}

\author{
Cui Zhe ${ }^{1, *}$, Yang Jinpei ${ }^{2}$ Wang Binru ${ }^{1}$ \\ ${ }^{1}$ School of Business, Nantong University, Nantong, China \\ ${ }^{2}$ School of Computer Sciences, University of Toronto, Mississauga, Canada
}

Email address:

7790@vip.163.com (Cui Zhe)

\section{To cite this article:}

Cui Zhe, Yang Jinpei, Wang Binru. The Analysis of Active Constraint of Equity Incentive in Listed Companies. Journal of Finance and Accounting. Vol. 3, No. 6, 2015, pp. 184-197. doi: 10.11648/j.jfa.20150306.13

\begin{abstract}
As a long-term compensation incentive, equity incentive can effectively solve the principal-agent problem, reducing managers' short-sighted behavior, improving the management efficiency of enterprises, thereby enhancing the performance of enterprises, and thus known as the "golden handcuffs" of enterprise incentive. One of the reasons that equity incentive is favored in listed companies is that it can curb the brain drain, namely the active constraint of equity incentive. But in recent years, the executive resign phenomenon has been more and more common in listed companies. For company executives and the core talented persons, the once "golden handcuffs" now turns into an elusive fantasy. A large number of executives who were once encouraged by the equity incentive are leaving their posts. The active constraint of equity incentive has not achieved the anticipated level. On the basis of the brief introduction to related concepts of the active constraint of equity incentive, this paper, which used the listed companies as the object of the study, selects 30 equity incentive plans which have a good active constraint of equity incentive to illustrate the present situation of the active constraint of equity incentive plan. After that, this paper selects 57 equity incentive plans which deadlines are 2012.12.31 and expounds three factors which affect the active constraint of equity incentive through the empirical method, then proposes three targeted improvement recommendations: improve the new share pricing system, design an effective equity incentive plan and improve relevant laws and regulations.
\end{abstract}

Keywords: Listed Companies, Equity Incentive, Active Constraint

\section{An Overview of Active Constraints of Equity Incentive}

\subsection{The Concept of Equity Incentive}

Equity incentive is a long - term compensation incentive. Through giving certain amounts of shares in the form of economic rights to directors, supervisors, senior management personnel, backbone employees and other personnel, making the actuator participate in the company decision-making, share the profits, take risks as shareholders, thereby carrying out their duties diligently for the long - term development of the enterprise, eventually improving the operating performance of enterprise's salary incentive system for a long time.

Equity incentive link up operators and shareholders' long - term interests together, and form a community based on interests, making the enterprise operators not only work for shareholders, but also work for themselves, so as to reduce the operator's short - sighted behavior, prompt managers to consider the long - term development of the enterprise. At the same time, under the equity incentive system, the company shareholders tend to authorize the board of directors on behalf of shareholders to sign the relevant agreement with incentive objects (including operators, enterprise's key employees, etc.). When incentive objects complete the performance targets indicated in the agreement or improve the company's value with the agent's efforts in a certain period, if the company's share price increases, the incentive objects can obtain the shares of the company directly according to certain favorable conditions, or indirectly purchase the shares of the company at a preferential rate, so as to promote the interest function of managers and shareholders reaching unanimity, and motivate managers to maximize shareholder interests. 


\subsection{The Active Constraints of Equity Incentive}

As a long-term equity incentive system to motivate the company executives and other employees in the process of enterprise operation and management, one of the effects of equity incentive is that it can curb the loss of executives and core technical personnel, simply as "stay". Equity incentive can improve incentive objects' enthusiasm, and stimulate the sense of responsibility through ownership arrangement, thus can increase productivity, improve the efficiency of capital operation and the enhancement of enterprise cohesion. Because the stakes are far more attracted to talented managers than cash reward, open ownership structure attracts and retains talented people. By setting the reasonable structure of period and quantity, managers' departure opportunity cost will increase, so as to achieve the aim of retain and motivate talented people. The active constraint of equity incentive is helpful to solve the problems of employed persons' retention and selection. It uses equity to attract and retain talent manager, eventually achieve the long-term development of the enterprise. The operator equity incentive mechanism can not only avoid the brain drain, but also attract more excellent talents for company to some extent, which is particularly important in today's knowledge-economy era.

\subsection{The Relations Between Incentive and Constraint of Equity Incentive}

(a) Incentive compatibility constraint

Due to the inconsistent of agent and principal's objective function, plus there are uncertainty and information asymmetry, the behavior of the agent may deviate from the objective function of the principal, and principals difficult to observe this deviation, they cannot supervise and restrict it effectively enough, which lead to the phenomenon that some agents damage the interests of principals. To solve this problem, what the client need to do is to design a system that makes both principals' and agents' interests effectively "bundling", to encourage the agent to behave in a manner which is most beneficial to principals, thereby the principal's benefit maximization can be implemented through the agent's utility maximization behavior, namely the realization of incentive compatibility. Incentive compatibility constraint can effectively solve the contradiction between individual interests and collective interests, and make person's behavior identical with the collective value maximization goals. Incentive leads to the occurrence of a behavior; Constraint regulates the new behavior, making it accord with certain direction and restricted within a certain time space, property.

(b) Incentive logic of equity incentive mechanism

Ideal incentive logic of equity incentive mechanism can be simply summed up as: the effort of the business management affects corporate performance, corporate performance affects stock prices, and stock prices affect the interests of business management. Companies offer equity incentive $\rightarrow$ incentive objects work hard $\rightarrow$ the goal of the company accomplished $\rightarrow$ shares rising $\rightarrow$ incentive objects benefit. If they don't work hard, company goals cannot be achieved, enterprises shares fall, the benefits of staff lost, etc.. All of this intangibly constraint incentive objects. Equity incentive mechanism accomplishes the designed purpose by a set of scientific and reasonable transferring link. If management's effort, corporate performance, the stock price, operation and management have high degree of correlation between the four related, active constraints of equity incentive effect will be better. If the market mechanism is not perfect, in the process of transmission, many market "noise" will interfere with each link, management layer's active constraints of equity incentive effect is not ideal, thus, equity incentive system's original purpose can hardly be achieved. Incentive mechanism reflects much more scarce human resources value compared to labor and capital, and the constraint mechanism avoid the short-term behavior of staff through the mutual benefits of both incentive objects and company, to achieve company goals.

(c) Rational allocation of incentive and constraint

No matter at home or abroad, equity incentive mechanism is a "double-edged sword".

If it was implemented well, everyone would be happy, and staffs would unit as one. If it was implemented bad, it would likely bring chaos, therefore, the equity incentive and constraint must have a reasonable configuration. For motivated employees, only when the constraints and incentives achieve a state of balance can they be loyalty and take the initiative to contribute the biggest value for the enterprise. Constraint and incentive are in each pan of the balance, only by establishing equivalent mechanism of incentive and constraint could promote the development of enterprise. Whether incentives are in place but constraints are insufficient or incentives are insufficient but constraints are excessive all will damage the interests of each side. For all companies, the incentives and constraints are both important; they shouldn't prefer one side or bias the other side. Form a related mechanism can better provide the basis for the company's development.

\section{The Present Situation of Listed Companies' Active Constraint of Equity Incentive Plan}

\subsection{The Summarization of the Present Situation}

Began in 2006, the equity incentive enter the stage of steady development in our country. According to Figure 2-1, there are total 44 listed companies unveil equity incentive plan to public in Shenzhen stock market and Shanghai stock market in 2006, and another 15 companies in 2007. In 2008, China's equity incentive developed into the real "gusher" stage. In 2012, enforcement of the listed companies' equity incentive scheme created a remarkable number of 118 , and has announced $26.58 \%$ of the total number of listed companies' equity incentive plan. By December 31, 2012, the Shenzhen stock market and Shanghai stock market have released 444 equity incentive plans in total. On the one hand, 
more and more companies implemented equity incentive plan, while on the other hand, the number of incentive objects' departure is also increasing. A seemingly magnificent equity incentive plan did not contain core brain drain. In 2010, A-share market has released 752 executives' demission announcement; daily 2 people "resign". In 2011, A-share market has released 1264 executives' demission announcement; daily 3.46 people "resign". After 2012, the "resign trend" of listed companies' executives continues to surge. By November 1, 2012, 413 main board executives resigned; 756 executives of the GEM and the SME board resigned. Among them, 45 main board chairmen and vice chairmen quitted, 108 general managers and deputy general managers quitted, 28 presidents and vice presidents quitted; 231 general managers of the GEM and the SME board resigned; the number of resigned chairmen of the board of directors increased 1.6 times. Equity incentive doesn't live up to people's expectation to have an active effect on retaining talents and staffs, active constraints of equity incentive is not significant, and the prospects of equity incentive plan are worrisome.

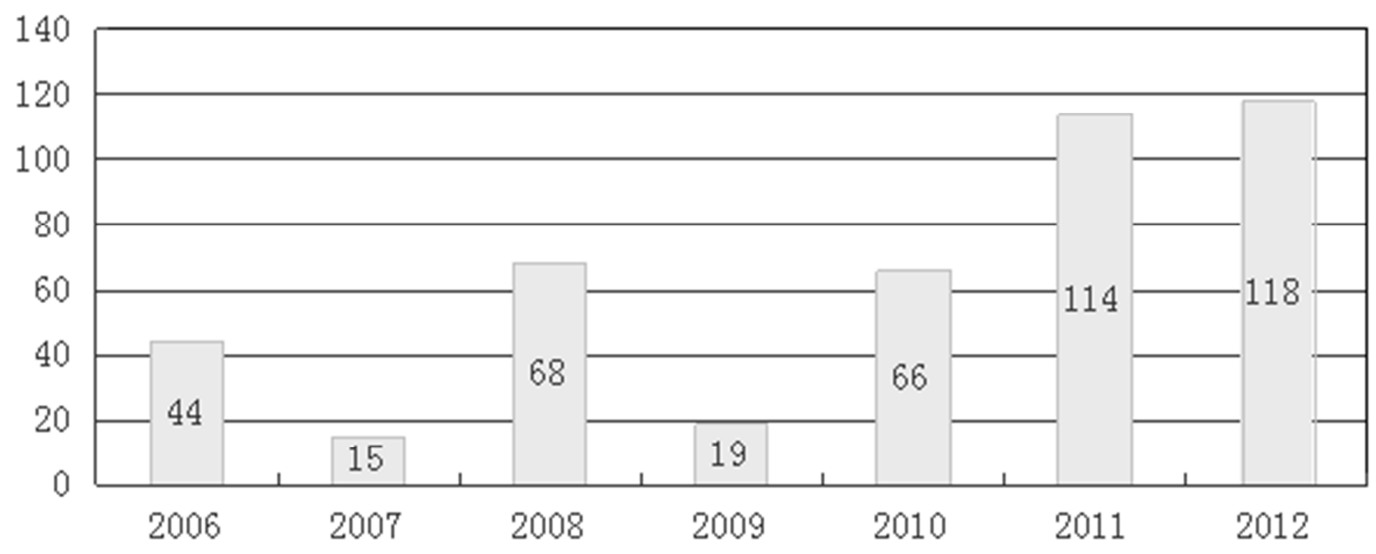

Figure 1. The statistical Figure of equity incentive plans'publishing situation for the first time in each year.

\subsection{The Analysis of Present Situation of Equity Incentive's Active Constraint of Listed Companies}

As we can know from the last para Figure, equity incentive doesn't have effect on retaining talents and staffs for many listed companies, yet there are many listed companies not only successfully implement equity incentive plans, but also its active constraint effect of equity incentive are very evident. Next, has been introduced in this article, we will select the 30 equity incentive plans as samples whose effect of equity incentive's active constraint are significantly (i.e. There is no motivated object resign during the equity incentive period). This paper analyzes the status quo of equity incentive's active constraint from four aspects: the equity incentive plan, stock source, the number of equity grants and vesting conditions (assessment indicators).

Here is the sample data:

Table 1. Samples of observably positive constraint of equity incentive plans.

\begin{tabular}{|c|c|c|c|c|c|}
\hline Code & Shortened form & Incentive mode & Source of stock & $\begin{array}{l}\text { The proportion of shares hold by objects } \\
\text { in total shares when the plan was sighed }\end{array}$ & $\begin{array}{l}\text { Performance } \\
\text { indicators }\end{array}$ \\
\hline 000566 & Hainan Pharmaceutical co. & stock option & orientate offer & $9.88 \%$ & A,B \\
\hline 000818 & Fangda Chemistry & stock option & orientate offer & $10.00 \%$ & A,B \\
\hline 000039 & Zhongji Group & stock option & orientate offer & $2.25 \%$ & A,B \\
\hline 000961 & Zhongnan Construction & stock option & orientate offer & $2.57 \%$ & A,B \\
\hline 000572 & Haima Automobile & stock option & orientate offer & $4.31 \%$ & A,B \\
\hline 000948 & Nantian Information & stock option & orientate offer & $2.40 \%$ & $\begin{array}{l}\mathrm{A}, \mathrm{B} \text { and the share of } \\
\text { main business profit }\end{array}$ \\
\hline 000488 & Chenming Paper & stock option & orientate offer & $5.13 \%$ & A,B \\
\hline 000667 & Celebrities' House Purchasing & stock option & orientate offer & $1.48 \%$ & $\mathrm{~A}, \mathrm{~B}$ and net profit \\
\hline 000671 & Sunshine Town & stock option & orientate offer & $9.10 \%$ & $\mathrm{~A}, \mathrm{~B}$ \\
\hline 000061 & Agricultural Products & restrictive stock & $\begin{array}{l}\text { offered by } \\
\text { shareholders }\end{array}$ & $6.76 \%$ & $\mathrm{~B}$, aggregate net profit \\
\hline 002029 & Septwolves & stock option & orientate offer & $1.31 \%$ & $\begin{array}{l}\mathrm{C} \text { and increasing rate of } \\
\text { EPS }\end{array}$ \\
\hline 002024 & Suning Appliance & restrictive stock & orientate offer & $1.21 \%$ & $\mathrm{~A}, \mathrm{C}$ \\
\hline 002281 & Guangxun Technology & stock option & orientate offer & $0.97 \%$ & $\mathrm{~A}, \mathrm{~B}, \mathrm{C}$ \\
\hline 002324 & Pleater & stock option & orientate offer & $2.22 \%$ & $\begin{array}{l}\text { A, B, sales volume of } \\
\text { product }\end{array}$ \\
\hline 002116 & China Haicheng & stock option & orientate offer & $3.50 \%$ & $\mathrm{~A}, \mathrm{~B}$ \\
\hline 002221 & Donghua Energy & restrictive stock & orientate offer & $1.31 \%$ & A,B \\
\hline
\end{tabular}




\begin{tabular}{llllll}
\hline Code & Shortened form & Incentive mode & Source of stock & $\begin{array}{l}\text { The proportion of shares hold by objects } \\
\text { in total shares when the plan was sighed }\end{array}$ & $\begin{array}{l}\text { Performance } \\
\text { indicators }\end{array}$ \\
\hline 002471 & SUSINO Umbrella & stock option & orientate offer & $2.97 \%$ & A,C \\
002367 & Tangrensheng Group & stock option & orientate offer & $9.42 \%$ & A,B \\
002250 & LianhuaTechnology & stock option & orientate offer & $6.72 \%$ & A,B \\
002301 & Qixin Stationery & restrictive stock & orientate offer & $2.94 \%$ & A,C \\
300208 & Hengshun Electric & stock option & orientate offer & $5.86 \%$ & A,B \\
300036 & Chaotu Software & stock option & orientate offer & $2.67 \%$ & A,B \\
300012 & Huace Detection & stock option & orientate offer & $1.53 \%$ & A,B,C \\
300012 & Huace Detection & stock & orientate offer & $1.53 \%$ & A,B,C \\
300015 & Aier Ophthalmology & stock option & orientate offer & $3.37 \%$ & A,B \\
300020 & Yinjiang co., ltd & stock option & orientate offer & $4.61 \%$ & A,B \\
300031 & Baotong & stock option & orientate offer & $1.26 \%$ & A,C \\
300064 & Diamond & stock option & orientate offer & $1.79 \%$ & A,B \\
300079 & Sumavision & stock option & orientate offer & $5.59 \%$ & A,B \\
300201 & Handler Special Vehicle co., ltd & stock option & orientate offer & $5.00 \%$ & A,B \\
\hline
\end{tabular}

PS: A: Growth rate of net profit; B: Yield rate of net assets; C: Increase rate of business revenue.

In this paper, all the data are from the listed companies of Shenzhen stock exchange's website announcement, sorted out by hand.

In this paper, the incentive objects we studied are that who completely left the original company, not including position changes, retirement and dismissal.

(a) The incentive mode of equity incentive plan

Among these 30 equity incentive plans, there are 25 equity incentive plan adopted the stock option model, accounted for 83.33\%. Agricultural Products, Suning Appliance, Donghua energy and Qixin Stationery these 4 incentive plans adopted the model of restricted stock, accounted for $13.33 \%$. Only one company's equity incentive plan adopted the combination incentive mode, Huace Detection uses a combination of stock option and stock appreciation rights incentive mode, and it's the only company who uses the stock appreciation rights incentive mode.

(b) The source of stock of equity incentive plan

Among these 30 equity incentive plans, there are 29 equity incentive plan adopted the shares source mode of orientate offer, only one company namely Agricultural Products uses the source mode offered by shareholders.

(c) The proportion of shares hold by incentive objects in the total share capital at the time of the plan was sighed

Figure 2 reflects the proportion of shares hold by incentive objects in the total share capital at the time of the plan was sighed. We can see from the Table, the proportion of the total share capital is mainly distributed in $1 \%-3 \%$ and $4 \%-10 \%$. Among them: there is one equity incentive plan under the proportion of $1 \%$ and the less, 8 equity incentive plans between $1 \%-2 \%$ (not including 2\%), 8 equity incentive plans between 2\% - 3\% (not including 3\%), one equity incentive plan between 3\% - 4\% (not including 4\%), 3 equity incentive plans between $4 \%$ - 5\% (not including 5\%), 4 equity incentive plans between $5 \%-6 \%$ (not including $6 \%$ ), 6 equity incentive plans above the proportion of $6 \%$ and the more. The proportion of offered shares in total capital in Fangda Chemistry accounted most, namely $10 \%$, which was least in Guangxun Technology, namely $0.97 \%$.

(d) The performance evaluation index system of equity incentive plan (vesting conditions)

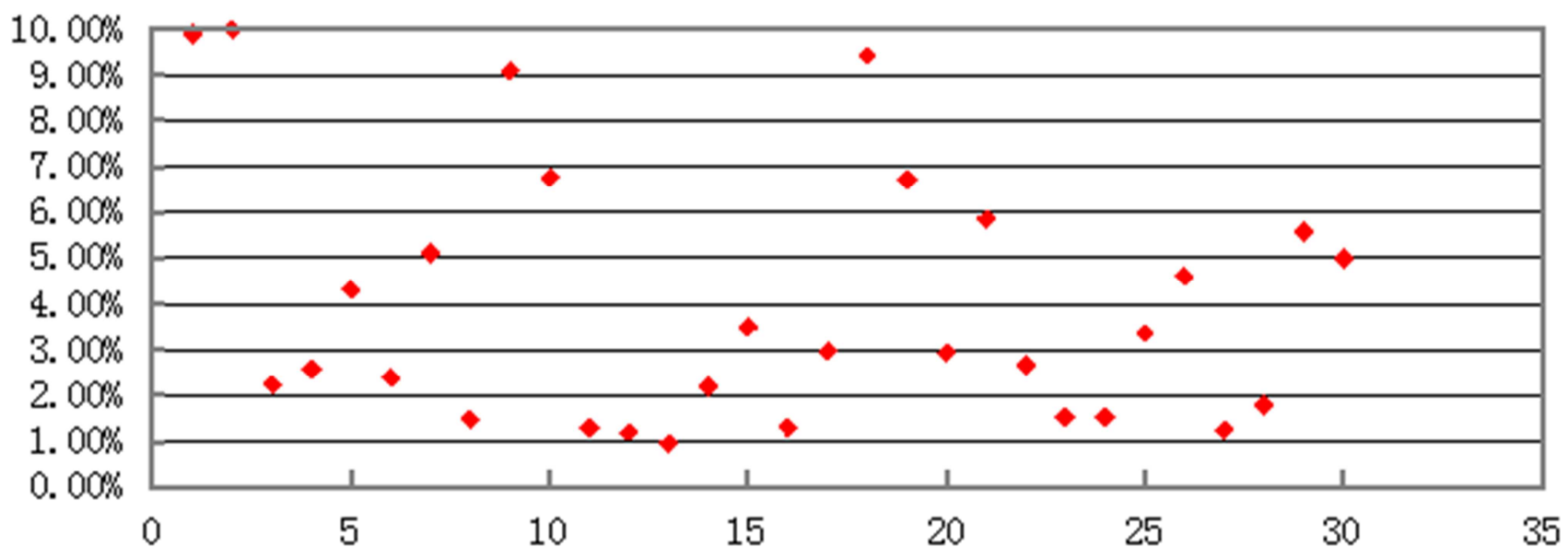

Figure 2. The proportion of shares hold by incentive objects in the total share capital at the time of the plan was sighed. 


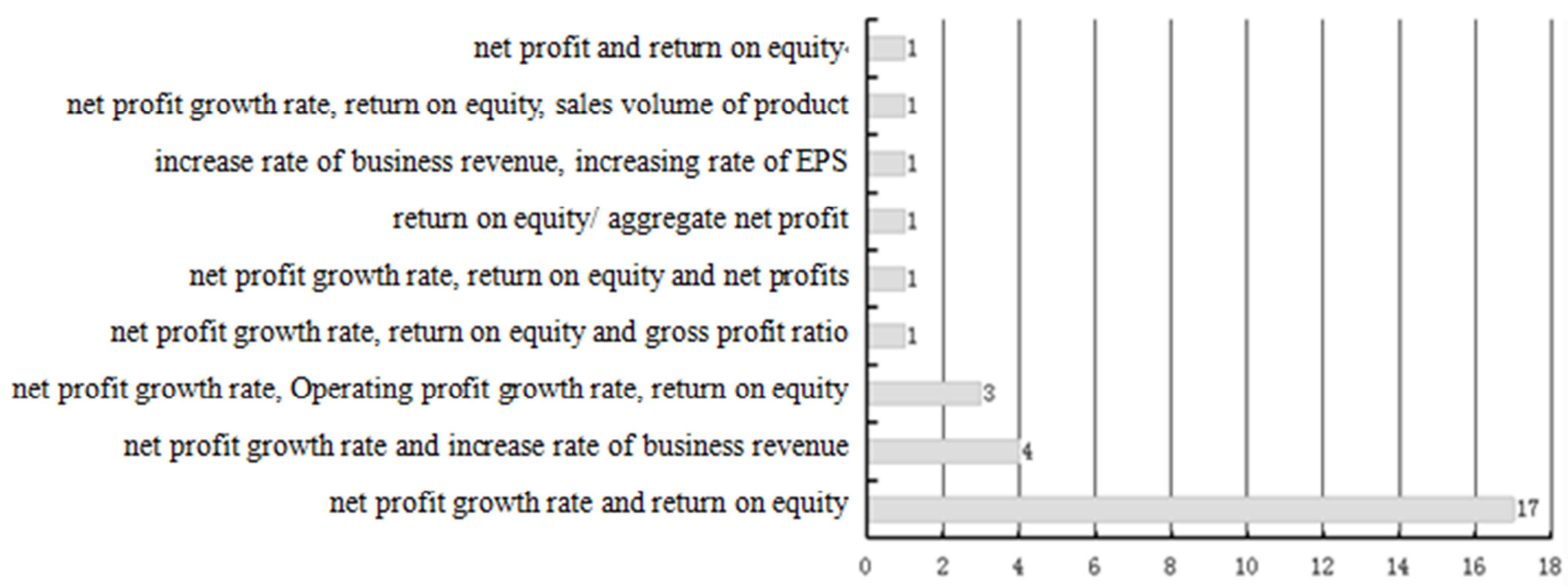

Figure 3. The performance evaluation index system of equity incentive plan.

According to Figure 3, in the 30 equity incentive plan, there are 23 take two indicators as a reference, and 6 take three indicators as a reference, there is only one agricultural product company as an assessment index. Here is the company's equity incentive performance assessment criteria in the next three years, "the company's net assets yield is not less than $2.5 \%, 6 \%$ and $4.5 \%$; if the company failed in achieve the above performance goals, the company must achieve three years continuous profitability, and three years total net profit is not less than 182 million yuan." There are 17 follow two indicators evaluation index of the equity incentive plan as a reference, they are trying to reach in the "net profit growth rate and the rate of return on net assets", "operating income growth rate and net profit growth rate" and 3 companies follow the order in the "growth rate of net profit and operating profit the growth rate, the rate of return on net assets", compared with other special "net profit growth rate, the proportion rate of return on net assets and the main business profit of the three indicators as evaluation index of the southern Information Company," to increase operating income growth rate and per share return rate of these two indicators as evaluation index of Septwolves etc.. Among them, there are 27 equity incentive plan have a net profit growth, there are 24 equity incentive plan with a net asset return rate of this indicator, there are 8 equity incentive in the business from income growth rate of this indicator, there are 2 equity incentive plan with a net profit according this indicator. The single index are "gross profit ratio", "sales" and "earnings per share growth rate".

\section{The Empirical Analysis of Factors Which Affect the Active Constraint of Equity Incentive}

\subsection{The Research Hypothesis}

(a) Publishing price and price ratio have negative correlation with the positive restraint effect of stock ownership incentive.
High publishing price and high price ratio are temptation for company's incentive, and just because the double high ("high publishing price and high price"), the stock could be estimated with higher price from shareholders, according to study, top managers could gain some important information that investors do not have, they know much more than investors about their accounting conditions and marketing result, and also they have a clearly decision about their future business. Therefore, managers have deep known in their business rationality, and however, they want a higher profit, some of top managers might resign and wait for cash-out if they make their shares could be sold with a higher price, this behavior has a big damage on the positive restraint effect of stock ownership incentive. The study group assumes that publishing price and price ration have negative correlation with the positive restraint effect of stock ownership incentive.

(b) The positive restraint effect of stock ownership incentive has positive correlation with the number of stock ownership incentive.

Majority of listing companies' managers have lower percentages than other shareholders in shares, and these low shares have restraint effect, and the money loss is too small to share company, and this little restraint effect is impossible to retain shareholders. Therefore, study group assume that the positive restraint effect of stock ownership incentive has positive correlation with the number of stock ownership incentive.

(c) The positive restraint effect of the multi-listing corporation of the performance evaluation index system of stock incentive plan is more obvious than performance evaluation index system of one-sided listing corporation.

Currently, the performance evaluation index of listing companies are net profit rate, net profit growth rate and other financial index, on the one hand, these indicators are biased in the short term, they will make the incentive object to focus on short-term financial results, and thus generate speculation, the long-term incentive to deviate from the equity incentive plan, on the other hand, these indicators do not consider the impact of macroeconomic fluctuations on the equity 
incentive effect. When the economy is booming, the performance evaluation index of the exercise conditions can be easily reached. But when the economy shrinks, most of the decline in performance of the company, the exercise conditions may become unreachable. Therefore, the study group assumes that the positive restraint effect of the multi listing corporation of the performance evaluation index system of stock incentive plan is more obvious than performance evaluation index system one-sided listing corporation.

\subsection{The Sample Selection and Variable Definition}

(a) The selection of the samples

As of December 31, 2012, 57 listed companies have successfully pushed out and implemented equity incentive plans, which selected from main boards, small and medium-sized boards, GEM boards of 19 industries, each one per industry. As for industries that did not push out equity incentive plans, such as the S class and A class of GEM, etc., we used equity incentive plans launched by other industries instead.

Here are the samples:

Table 2. Samples of main boards in Shenzhen Stock Exchange.

\begin{tabular}{|c|c|c|c|c|c|c|c|c|c|c|}
\hline Code & $\begin{array}{l}\text { Shortened } \\
\text { form }\end{array}$ & Type & $\begin{array}{l}\text { The time of } \\
\text { equity incentive } \\
\text { plans' } \\
\text { publishing }\end{array}$ & $\begin{array}{l}\text { The } \\
\text { number of } \\
\text { objects } \\
(* 10000)\end{array}$ & $\begin{array}{l}\text { The } \\
\text { proportion } \\
\text { in total } \\
\text { shares when } \\
\text { signed }\end{array}$ & $\begin{array}{l}\text { Performance } \\
\text { indicators }\end{array}$ & $\begin{array}{l}\text { Offering } \\
\text { price }\end{array}$ & $\begin{array}{l}\text { PE } \\
\text { ratio }\end{array}$ & $\begin{array}{l}\text { In(total } \\
\text { assets) }\end{array}$ & $\begin{array}{l}\text { Any } \\
\text { dimission } \\
\text { during } \\
\text { incentive } \\
\text { time }\end{array}$ \\
\hline 000561 & $\begin{array}{l}\text { Fenghuo } \\
\text { Electronics }\end{array}$ & C Manufacturing & 2011-12-18 & 580.3 & $0.99 \%$ & $\begin{array}{l}\mathrm{B}, \mathrm{C} \text { and growth } \\
\text { rate of } \mathrm{r} \& \mathrm{~d} \\
\text { expenditure }\end{array}$ & 4.55 & 8.75 & 12 & NO \\
\hline 000039 & $\begin{array}{l}\text { Zhongji } \\
\text { Group }\end{array}$ & C Manufacturing & $2010-9-28$ & 6000 & $2.25 \%$ & A,B & 8.5 & 12.3 & 15.66 & $\mathrm{NO}$ \\
\hline 000100 & TCL Group & C Manufacturing & 2011-1-29 & 15502.56 & $1.83 \%$ & A & 30 & 46.88 & 15.89 & YES \\
\hline 000690 & $\begin{array}{l}\text { Baoxin } \\
\text { Energy }\end{array}$ & D Utilities & $2006-7-20$ & 2700 & $9.84 \%$ & A,B & 7.08 & 20.15 & 13.77 & YES \\
\hline 000961 & $\begin{array}{l}\text { Zhongnan } \\
\text { Construction }\end{array}$ & E Construction & $2011-3-25$ & 3000 & $2.57 \%$ & A,B & 4.08 & 11.33 & 14.08 & $\mathrm{NO}$ \\
\hline 000996 & CIFCO & F Retail & $2008-1-28$ & 1100 & $9.57 \%$ & A & 8.28 & 39.58 & 11.05 & YES \\
\hline 000572 & $\begin{array}{l}\text { Haima } \\
\text { Automobile }\end{array}$ & C Manufacturing & $2012 / 2 / 30$ & 177 & $4.31 \%$ & A,B & 6.68 & 7.59 & 14.05 & $\mathrm{NO}$ \\
\hline 000790 & $\begin{array}{l}\text { Huashen } \\
\text { Group }\end{array}$ & C Manufacturing & $2010-3-16$ & 800 & $4.01 \%$ & A,B & 100 & 58 & 11.36 & YES \\
\hline 000948 & $\begin{array}{l}\text { Nantian } \\
\text { Info. }\end{array}$ & $\begin{array}{l}\text { I Information } \\
\text { Technology }\end{array}$ & $2011-5-3$ & 295 & $2.40 \%$ & $\begin{array}{l}\text { A,B and main } \\
\text { business profits }\end{array}$ & 8.13 & 20 & 12.3 & $\mathrm{NO}$ \\
\hline 000488 & $\begin{array}{l}\text { Chenming } \\
\text { Paper }\end{array}$ & C Manufacturing & $2006-10-10$ & 7000 & $5.13 \%$ & A,B & 20.8 & 30 & 15.38 & $\mathrm{NO}$ \\
\hline 000667 & $\begin{array}{l}\text { Celebrities' } \\
\text { House } \\
\text { Purchasing }\end{array}$ & K Real estate & $2012-6-25$ & 3000 & $1.48 \%$ & $\begin{array}{l}\text { A,B and net } \\
\text { profits }\end{array}$ & 15.23 & 37.62 & 14.08 & $\mathrm{NO}$ \\
\hline 000932 & $\begin{array}{l}\text { Hualing } \\
\text { Steel }\end{array}$ & C Manufacturing & $2008-1-15$ & 300 & $1.30 \%$ & $\mathrm{~B}, \mathrm{C}$ & 5.3 & 15.23 & 15.69 & NO \\
\hline 000826 & $\begin{array}{l}\text { Sangde } \\
\text { Environment }\end{array}$ & $\begin{array}{l}\text { N Public } \\
\text { environment }\end{array}$ & $2012-4-12$ & 90 & $2.21 \%$ & A,B & 14.9 & 38 & 13.36 & YES \\
\hline 000002 & China Vanke & K Real estate & $2010-10-25$ & 11000 & $1.00 \%$ & A,B & 31.53 & 30.51 & 17.45 & YES \\
\hline 000921 & $\begin{array}{l}\text { Hisense } \\
\text { Kelon }\end{array}$ & C Manufacturing & $2010-12-3$ & 1951 & $1.51 \%$ & A,B & 9.98 & 14.9 & 13.72 & $\mathrm{NO}$ \\
\hline 000671 & $\begin{array}{l}\text { Sunshine } \\
\text { Town }\end{array}$ & C Manufacturing & 2011-1-12 & 4875 & $9.10 \%$ & $\mathrm{~A}, \mathrm{C}$ & 1 & 20 & 14.31 & $\mathrm{NO}$ \\
\hline 000568 & $\begin{array}{l}\text { Luzhou } \\
\text { Laojiao }\end{array}$ & C Manufacturing & $2010-2-9$ & 1344 & $0.96 \%$ & A,B & 5.83 & 30.5 & 14.26 & YES \\
\hline 000009 & China Baoan & S Comprehensive & $2011-1-28$ & 7500 & $6.88 \%$ & A,B & 3 & 30.8 & 14.1 & YES \\
\hline
\end{tabular}

PS: A: Growth rate of net profit; B: Yield rate of net assets; C: Increase rate of business revenue. 
Table 3. Samples of small and medium enterprise (SME) boards.

\begin{tabular}{|c|c|c|c|c|c|c|c|c|c|c|}
\hline Code & $\begin{array}{l}\text { Shortened } \\
\text { form }\end{array}$ & Type & $\begin{array}{l}\text { The time of } \\
\text { equity incentive } \\
\text { plans' } \\
\text { publishing }\end{array}$ & $\begin{array}{l}\text { The } \\
\text { number } \\
\text { of objects } \\
(* 10000)\end{array}$ & $\begin{array}{l}\text { The } \\
\text { proportion in } \\
\text { total shares } \\
\text { when signed }\end{array}$ & $\begin{array}{l}\text { Performance } \\
\text { indicators }\end{array}$ & $\begin{array}{l}\text { Offering } \\
\text { price }\end{array}$ & $\begin{array}{l}P E \\
\text { ratio }\end{array}$ & $\begin{array}{l}\text { In(total } \\
\text { assets) }\end{array}$ & $\begin{array}{l}\text { Any } \\
\text { dimission } \\
\text { during } \\
\text { incentive time }\end{array}$ \\
\hline 002477 & $\begin{array}{l}\text { Chuying } \\
\text { Agro-pastoral }\end{array}$ & $\begin{array}{l}\text { A Agriculture \& } \\
\text { Farming }\end{array}$ & $2012-3-13$ & 234 & $0.88 \%$ & $\mathrm{~A}, \mathrm{~B}$ & 35 & 60.98 & 13.01 & YES \\
\hline 002029 & Septwolves & C Manufacturing & 2010-11-15 & 370 & $1.31 \%$ & $\begin{array}{l}\text { sales volume } \\
\text { and earnings } \\
\text { per share }\end{array}$ & 7.45 & 17.91 & 13.22 & YES \\
\hline 002327 & Fuanna & C Manufacturing & $2012-2-4$ & 284.4 & $1.76 \%$ & A & 30 & 46.88 & 12.24 & YES \\
\hline 002479 & $\begin{array}{l}\text { Fuchun } \\
\text { Environment }\end{array}$ & D Utilities & $212 / 11 / 23$ & 600 & $1.40 \%$ & $\mathrm{~A}, \mathrm{~B}$ & 25.8 & 73.71 & 12.56 & YES \\
\hline 002081 & $\begin{array}{l}\text { Golden } \\
\text { Mantis }\end{array}$ & E Construction & $2008-7-10$ & 300 & $2.13 \%$ & $\mathrm{~A}, \mathrm{~B}$ & 12.8 & 26.43 & 14.1 & YES \\
\hline 002024 & $\begin{array}{l}\text { Suning } \\
\text { Appliance }\end{array}$ & F Retail & $2010-8-25$ & 8496 & $1.21 \%$ & $\begin{array}{l}\text { A, growth } \\
\text { rate of sales } \\
\text { revenue }\end{array}$ & 16.33 & 11.26 & 15.85 & NO \\
\hline 002065 & $\begin{array}{l}\text { Donghua } \\
\text { Software }\end{array}$ & $\begin{array}{l}\text { I Information } \\
\text { technology }\end{array}$ & 2011-12-20 & 1180.7 & $2.22 \%$ & A & 14.5 & 21.64 & 12.9 & YES \\
\hline 002306 & $\begin{array}{l}\text { Xiangeqing } \\
\text { Co., Ltd. }\end{array}$ & $\begin{array}{l}\mathrm{H} \\
\text { Accommodation } \\
\text { \& Catering }\end{array}$ & 2011-1-10 & 1100 & $5.50 \%$ & $\mathrm{~A}, \mathrm{~B}$ & 18.9 & 59.25 & 12.31 & YES \\
\hline 002063 & $\begin{array}{l}\text { Yuanguang } \\
\text { Software }\end{array}$ & $\begin{array}{l}\text { I Information } \\
\text { technology }\end{array}$ & $2009-11-20$ & 1001.74 & $5.07 \%$ & $\mathrm{~A}, \mathrm{~B}$ & 5.8 & 24.68 & 11.84 & YES \\
\hline 002281 & $\begin{array}{l}\text { Guangxun } \\
\text { Tech. }\end{array}$ & C Manufacturing & $2011-5-10$ & 155.6 & $0.97 \%$ & $\begin{array}{l}\text { net } \\
\text { profits,B,C }\end{array}$ & 16 & 35.37 & 12.26 & NO \\
\hline 002305 & $\begin{array}{l}\text { Nanguo } \\
\text { House } \\
\text { Purchasing }\end{array}$ & K Real estate & $2011-6-28$ & 2400 & $2.50 \%$ & $\mathrm{~B}, \mathrm{C}$ & 12.3 & 36.18 & 13.38 & YES \\
\hline 002324 & $\begin{array}{l}\text { Shanghai } \\
\text { Pret } \\
\text { Composites }\end{array}$ & C Manufacturing & $2010-11-23$ & 300 & $2.22 \%$ & $\begin{array}{l}\text { A,B and sales } \\
\text { volume }\end{array}$ & 22.5 & 86.54 & 11.94 & NO \\
\hline 002116 & $\begin{array}{l}\text { China } \\
\text { Haicheng }\end{array}$ & $\begin{array}{l}\text { M Scientific } \\
\text { research }\end{array}$ & $2012-3-5$ & 399 & $3.50 \%$ & $\mathrm{~A}, \mathrm{~B}$ & 6.88 & 29.91 & 12.58 & NO \\
\hline 002269 & $\begin{array}{l}\text { Meibang } \\
\text { Clothes }\end{array}$ & C Manufacturing & $2010-4-20$ & 581.4 & $0.52 \%$ & $\mathrm{~A}, \mathrm{~B}$ & 19.76 & 22.74 & 13.46 & YES \\
\hline 002310 & $\begin{array}{l}\text { Eastern } \\
\text { Garden }\end{array}$ & E Construction & 2011-1-15 & 378.98 & $2.52 \%$ & $\mathrm{~A}, \mathrm{~B}$ & 58.6 & 50.96 & 13.42 & YES \\
\hline 002221 & $\begin{array}{l}\text { Donghua } \\
\text { Energy }\end{array}$ & F Retail & $2011-3-27$ & 290 & $1.31 \%$ & $\mathrm{~A}, \mathrm{~B}$ & 5.69 & 29.95 & 13.1 & NO \\
\hline 002174 & $\begin{array}{l}\text { SUSINO } \\
\text { Umbrella }\end{array}$ & C Manufacturing & $2011-5-12$ & 246 & $2.97 \%$ & $\mathrm{~A}, \mathrm{C}$ & 5.68 & 22.72 & 11.14 & NO \\
\hline 002376 & $\begin{array}{l}\text { Shandong } \\
\text { New Beiyang }\end{array}$ & C Manufacturing & $2012-3-10$ & 150 & $1.00 \%$ & $\mathrm{~A}, \mathrm{~B}$ & 22.58 & 46.08 & 2.87 & NO \\
\hline 002301 & $\begin{array}{l}\text { Qixin } \\
\text { Stationery }\end{array}$ & C Manufacturing & 2011-6-28 & 491 & $2.63 \%$ & $\mathrm{~A}, \mathrm{C}$ & 20 & 42.67 & 11.97 & NO \\
\hline
\end{tabular}

PS: A: Growth rate of net profit; B: Yield rate of net assets; C: Increase rate of business revenue.

Table 4. Samples of growth enterprise market (GEM) boards.

\begin{tabular}{|c|c|c|c|c|c|c|c|c|c|c|}
\hline Code & $\begin{array}{l}\text { Shortened } \\
\text { form }\end{array}$ & Type & $\begin{array}{l}\text { The time of } \\
\text { equity incentive } \\
\text { plans' } \\
\text { publishing }\end{array}$ & $\begin{array}{l}\text { The } \\
\text { number of } \\
\text { objects } \\
(* 10000)\end{array}$ & $\begin{array}{l}\text { The } \\
\text { proportion in } \\
\text { total shares } \\
\text { when signed }\end{array}$ & $\begin{array}{l}\text { Performanc } \\
\text { e indicators }\end{array}$ & $\begin{array}{l}\text { Offering } \\
\text { price }\end{array}$ & $\begin{array}{l}\mathrm{PE} \\
\text { ratio }\end{array}$ & $\begin{array}{l}\text { In(total } \\
\text { assets) }\end{array}$ & $\begin{array}{l}\text { Any } \\
\text { dimission } \\
\text { during } \\
\text { incentive time }\end{array}$ \\
\hline 300138 & $\begin{array}{l}\text { Chenguang } \\
\text { Biology }\end{array}$ & $\begin{array}{l}\text { C } \\
\text { Manufacturing }\end{array}$ & 2011.3.29 & 300 & $3.34 \%$ & A,B & 30 & 47.62 & 11.88 & YES \\
\hline 300208 & $\begin{array}{l}\text { Hengshun } \\
\text { Electric }\end{array}$ & $\begin{array}{l}\text { C } \\
\text { Manufacturing }\end{array}$ & 2011.6 .28 & 410 & $5.86 \%$ & A,B & 25 & 34.98 & 11.56 & NO \\
\hline 300004 & $\begin{array}{l}\text { Nanfeng } \\
\text { Shares }\end{array}$ & $\begin{array}{l}\text { C } \\
\text { Manufacturing }\end{array}$ & 2011.2 .8 & 640 & $3.40 \%$ & A,B & 22.89 & 34.47 & 11.6 & YES \\
\hline 300177 & Hi-Target & $\begin{array}{l}\text { C } \\
\text { Manufacturing }\end{array}$ & 2011.6 .2 & 213.1 & $4.26 \%$ & A,B & 46.8 & 55.06 & 11.45 & YES \\
\hline 300117 & Jiayu Shares & E Construction & 2012.7 .4 & 1068 & $4.92 \%$ & A,B & 26 & 34.21 & 12.34 & YES \\
\hline 300005 & Pathfinder & $\begin{array}{l}\text { C } \\
\text { Manufacturing }\end{array}$ & 2012.2 .9 & 455 & $1.31 \%$ & A,B & 19 & 39.6 & 11.6 & YES \\
\hline
\end{tabular}




\begin{tabular}{|c|c|c|c|c|c|c|c|c|c|c|}
\hline Code & $\begin{array}{l}\text { Shortened } \\
\text { form }\end{array}$ & Type & $\begin{array}{l}\text { The time of } \\
\text { equity incentive } \\
\text { plans' } \\
\text { publishing }\end{array}$ & $\begin{array}{l}\text { The } \\
\text { number of } \\
\text { objects } \\
(* 10000)\end{array}$ & $\begin{array}{l}\text { The } \\
\text { proportion in } \\
\text { total shares } \\
\text { when signed }\end{array}$ & $\begin{array}{l}\text { Performanc } \\
\text { e indicators }\end{array}$ & $\begin{array}{l}\text { Offering } \\
\text { price }\end{array}$ & $\begin{array}{l}\mathrm{PE} \\
\text { ratio }\end{array}$ & $\begin{array}{l}\text { In(total } \\
\text { assets) }\end{array}$ & $\begin{array}{l}\text { Any } \\
\text { dimission } \\
\text { during } \\
\text { incentive time } \\
\end{array}$ \\
\hline 300007 & $\begin{array}{l}\text { Hanwei } \\
\text { Electronic }\end{array}$ & $\begin{array}{l}\mathrm{C} \\
\text { Manufacturing }\end{array}$ & 2011.5.9 & 310 & $2.63 \%$ & $\mathrm{~A}, \mathrm{~B}$ & 27 & 45.15 & 11.21 & YES \\
\hline 300025 & $\begin{array}{l}\text { Huaxing } \\
\text { Entrepreneur } \\
\text {-ship }\end{array}$ & $\begin{array}{l}\text { I Information } \\
\text { technology }\end{array}$ & 2010.10 .23 & 170 & $2.13 \%$ & $\mathrm{~A}, \mathrm{~B}$ & 19.65 & 33.88 & 11.42 & YES \\
\hline 300017 & $\begin{array}{l}\text { Wangsu } \\
\text { Technology }\end{array}$ & $\begin{array}{l}\text { I Information } \\
\text { technology }\end{array}$ & 2010.12 .19 & 550 & $3.57 \%$ & $\mathrm{~A}, \mathrm{~B}, \mathrm{C}$ & 24 & 47.06 & 11.5 & YES \\
\hline 300036 & $\begin{array}{l}\text { Chaotu } \\
\text { Software }\end{array}$ & $\begin{array}{l}\text { I Information } \\
\text { technology }\end{array}$ & 2011.2.24 & 200 & $2.67 \%$ & $\mathrm{~A}, \mathrm{~B}$ & 19.6 & 37.69 & 11.23 & NO \\
\hline 300043 & $\begin{array}{l}\text { Xinghui Car } \\
\text { Model }\end{array}$ & $\begin{array}{l}\mathrm{C} \\
\text { Manufacturing }\end{array}$ & 2011.11 .4 & 340 & $2.15 \%$ & $\mathrm{~A}, \mathrm{~B}$ & 43.98 & 68.61 & 11.94 & YES \\
\hline 300058 & Blue Focus & L Com & 2010.12 .09 & 700 & $5.83 \%$ & A & 33 & 50.54 & 12.46 & YES \\
\hline 300012 & $\begin{array}{l}\text { Huace } \\
\text { Detection }\end{array}$ & $\begin{array}{l}\text { M scientific } \\
\text { research }\end{array}$ & 2011.8 .8 & 309 & $1.53 \%$ & $\mathrm{~A}, \mathrm{~B}, \mathrm{C}$ & 25.78 & 44.45 & 11.47 & NO \\
\hline 300070 & Originwater & $\begin{array}{l}\text { N Public } \\
\text { Environment }\end{array}$ & 2010.08 .04 & 400 & $2.72 \%$ & $\mathrm{~A}, \mathrm{~B}, \mathrm{C}$ & 69 & 70.84 & 11.1 & YES \\
\hline 300045 & Hwa Create & $\begin{array}{l}\text { C } \\
\text { Manufacturing }\end{array}$ & 2011.11 .12 & 200 & $2.99 \%$ & A & 30.7 & 56.85 & 11.32 & YES \\
\hline 300170 & $\begin{array}{l}\text { Hande } \\
\text { Information }\end{array}$ & $\begin{array}{l}\text { I Information } \\
\text { technology }\end{array}$ & 2011.4.27 & 656 & $4.05 \%$ & $\mathrm{~A}, \mathrm{~B}$ & 25.32 & 53.63 & 11.73 & YES \\
\hline 300015 & $\begin{array}{l}\text { Aier } \\
\text { Ophthalmolo } \\
\text { gy }\end{array}$ & Q Health & 2010.10 .31 & 900 & $3.37 \%$ & A,B & 28 & 45.9 & 12.17 & NO \\
\hline 300133 & Huace Movie & $\begin{array}{l}\text { R Cultural } \\
\text { Transmission }\end{array}$ & 2011.7 .15 & 447.5 & $3.96 \%$ & A,B & 68 & 64.03 & 11.96 & YES \\
\hline 300168 & $\begin{array}{l}\text { Wanda } \\
\text { Information }\end{array}$ & $\begin{array}{l}\text { I Information } \\
\text { technology }\end{array}$ & 2011.3 .23 & 501.6 & $4.18 \%$ & $\mathrm{~A}, \mathrm{~B}, \mathrm{C}$ & 28 & 65.12 & 11.93 & YES \\
\hline
\end{tabular}

PS: A: Growth rate of net profit; B: Yield rate of net assets; C: Increase rate of business revenue.

In this paper, all the data are from the listed companies of Shenzhen stock exchange's website announcement, sorted out by hand.

In this paper, the incentive objects we studied are that who completely left the original company, not including position changes, retirement and dismissal.

(b) The definition of the variable

A. Explained variable (incentive objects' resignation variables)

To quantify the effect of active constraints of equity incentive is to analysis whether there exists talent loss, as to say if resignation phenomenon of incentive objects exists in the listed companies. So this article involves an explained variable, namely the variable of incentive objects' resignation. This belonged to classification variables, and was divided into two cases: resign or not. Respectively, the value $1,0,1$ means there exists resignation of motivated objects; the effect of the active constraints is not very significant. 0 means no motivated objects resign, namely active constraint effect is remarkable.

B. Explanatory variable

(1) Issue price

After inquiring stage during these companies' initial public offering, we select the finally decides price as the issue price. The basic unit of the variable is yuan.

(2) Issuance price-earnings-ratio

The issuing price divided by earnings per share is $\mathrm{P} / \mathrm{E}$ ratio, the lower of recently audited net profit after deducting non-recurring gains and losses, divided by total equity after this offering, is the earnings per share.

$\mathrm{P} / \mathrm{E}$ ratio depends on not only the issue price, but also earnings per share, it reflects how many times the offering price is as many as earnings per share, so $\mathrm{P} / \mathrm{E}$ ratio reflects the difference between the market valuation of the stock and the current actual profitability of enterprises.

(3) Number of items of equity incentive evaluation index

Number of items of equity incentive evaluation index is in each sample. The basic unit of the variable is one.

(4) The amount of equity hold by incentive objects accounts for the proportion of the total equity (the average proportion of authorization)

The amount of equity hold by incentive objects accounts for the proportion of the total equity = the proportion of shares of equity incentive plans in the total equity/the number of objects.

C. Control variable (the scale of companies)

The scale of company is not the key point of this article, but it is also the important factors that affect the dependent variable, so must be entered into the regression equation. This paper uses natural logarithm of total assets as the company scale factors, namely the control variable is ln (total assets). We accept listed companies' total assets in December 31,2012 as the "total assets". 
Table 5. The definition of the variable.

\begin{tabular}{ll}
\hline $\begin{array}{l}\text { Explained } \\
\text { variable }\end{array}$ & Incentive objects' resignation variables \\
\hline & $\begin{array}{l}\text { Issue price } \\
\text { Issuance price-earnings-ratio }\end{array}$ \\
$\begin{array}{l}\text { Explanatory } \\
\text { variable }\end{array}$ & $\begin{array}{l}\text { Number of items of equity incentive evaluation index } \\
\text { The amount of equity hold by incentive objects accounts } \\
\text { for the proportion of the total equity (the average } \\
\text { proportion of authorization) } \\
\text { Variable }\end{array}$ \\
\hline
\end{tabular}

\subsection{The Design of Empirical Model}

This paper adopted the Logistic regression model to Logit (incentive objects resignation) conduct research, the Logistic regression model is mainly used in the regression analysis of reaction variables (dependent variable) as the classification, therefore it's very suitable to describe the probability of occurrence of certain states and what influences the probability. In this paper, to quantify the effect of active constraints of equity incentive is to analysis whether there exists talent loss, as to say if resignation phenomenon of incentive objects exists in the listed companies, values of the dependent variables are divided into "resign" and "not resign". By using Logistic regression model, we can well reflect the relationships between influencing factors and incentive objects' resignation. In this paper, the model is as follows:

$$
\begin{aligned}
=C(1)+ & C(2) \times \text { issue price }+C(3) \times P / E \text { ratio }+C(4) \times \text { number of items of evaluation index } \\
& +C(5) \times \text { the averageproportion of authorization }+C(6) \times \ln (\text { total assets })
\end{aligned}
$$

\subsection{The Descriptive Analysis of the Variable}

(a) Descriptive analysis

Following Table is the descriptive analysis of the variables:

\begin{tabular}{|c|c|c|c|c|c|c|}
\hline Independent variable & Dependent variable & Sample volume & Mean value & Standard deviation & Maximum & Minimum \\
\hline \multirow{3}{*}{ Issue price } & 1 & 35 & 26.57 & 20.60 & 100 & 3 \\
\hline & 0 & 22 & 9.65 & 18.64 & 25.78 & 1 \\
\hline & Summation & 57 & 21.56 & 19.33 & 100 & 1 \\
\hline \multirow{3}{*}{$\mathrm{P} / \mathrm{E}$ ratio } & 1 & 35 & 44.31 & 48.30 & 73.71 & 17.91 \\
\hline & 0 & 22 & 22.45 & 33.50 & 86.54 & 5.68 \\
\hline & Summation & 57 & 33.65 & 40.66 & 86.54 & 5.68 \\
\hline \multirow{3}{*}{$\begin{array}{l}\text { Number of items of } \\
\text { evaluation index }\end{array}$} & 1 & 35 & 1.94 & 0.47 & 3 & 1 \\
\hline & 0 & 22 & 2.27 & 0.45 & 3 & 2 \\
\hline & Summation & 57 & 2.07 & 0.47 & 3 & 1 \\
\hline \multirow{3}{*}{$\begin{array}{l}\text { The average proportion of } \\
\text { authorization }\end{array}$} & 1 & 35 & $0.03 \%$ & $0.025 \%$ & $0.107 \%$ & $0.0001 \%$ \\
\hline & 0 & 22 & $0.06 \%$ & $0.084 \%$ & $0.27 \%$ & $0.0049 \%$ \\
\hline & Summation & 57 & $0.04 \%$ & $0.059 \%$ & $0.27 \%$ & $0.0049 \%$ \\
\hline \multirow{3}{*}{$\ln$ (total assets) } & 1 & 35 & 13.68 & 1.41 & 17.45 & 11.5 \\
\hline & 0 & 22 & 12.155 & 2.68 & 15.85 & 2.87 \\
\hline & Summation & 57 & 13.09 & 1.97 & 17.45 & 2.87 \\
\hline
\end{tabular}

Table 6. The descriptive analysis of samples which resignation exists in or not.

We can see from the table above, the average of offering price and $\mathrm{P} / \mathrm{E}$ ratio of listed companies where resignation exists are higher than the average of those companies where incentive objects' resignation does not take place.

For number of items of equity incentive's evaluation index, the average of which in the listed companies where resignation exists are less than that in companies where incentive objects' resignation does not take place. That is to say, the separation rate of listed companies whose evaluation index system of performance was one-sided was higher than that of listed companies whose evaluation index was multivariate.

Equally, for number of shares hold by equity incentive objects accounted for the proportion of the total equity, the average of which in the listed companies where resignation exists are less than that in companies where incentive objects' resignation does not take place, the latter is two times as many as the former.

For $\ln$ (total assets), the average of which in the listed companies where resignation exists are little bit higher than that in companies where incentive objects' resignation does not take place, that is to say, incentive objects' quit rate of listed companies whose scale are smaller is lower.

(b) Correlation analysis

We have carried on the correlation analysis about five independent variables based on spss16.0 software. Analytical data are shown in table 7 below:

Table 7. Analysis results among independent variables' correlation.

\begin{tabular}{lccccc}
\hline & $\mathbf{X 1}$ & $\mathbf{X 2}$ & $\mathbf{X 3}$ & $\mathbf{X 4}$ & $\mathbf{X 5}$ \\
\hline $\begin{array}{l}\text { X1 Pearson } \\
\text { Correlation }\end{array}$ & 1 & $.524 * *$ & -.097 & -.170 & -.234 \\
Sig.(2-detailed) & & .000 & .472 & .206 & .097 \\
\hline
\end{tabular}




\begin{tabular}{|c|c|c|c|c|c|}
\hline & $\mathbf{X 1}$ & $\mathrm{X} 2$ & $\mathbf{X} 3$ & $\mathrm{X} 4$ & X5 \\
\hline $\mathrm{N}$ & 57 & 57 & 57 & 57 & 57 \\
\hline $\begin{array}{l}\text { X2 Pearson } \\
\text { Correlation }\end{array}$ & $.524 * *$ & 1 & -.018 & -.109 & $-.304 *$ \\
\hline Sig.(2-detailed) & .000 & & .892 & .421 & .022 \\
\hline $\mathrm{N}$ & 57 & 57 & 57 & 57 & 57 \\
\hline $\begin{array}{l}\text { X3 Pearson } \\
\text { Correlation }\end{array}$ & -.097 & -.018 & 1 & .214 & .016 \\
\hline Sig.(2-detailed) & .472 & .892 & & .110 & .908 \\
\hline $\mathrm{N}$ & 57 & 57 & 57 & 57 & 57 \\
\hline $\begin{array}{l}\text { X4 Pearson } \\
\text { Correlation }\end{array}$ & -.170 & -.109 & .214 & 1 & .184 \\
\hline Sig.(2-detailed) & .206 & .421 & .110 & & .170 \\
\hline $\mathrm{N}$ & 57 & 57 & 57 & 57 & 57 \\
\hline $\begin{array}{l}\text { X5 Pearson } \\
\text { Correlation }\end{array}$ & -.234 & $-.304 *$ & .016 & .184 & 1 \\
\hline Sig.(2-detailed) & .097 & .022 & .908 & .170 & \\
\hline $\mathrm{N}$ & 57 & 57 & 57 & 57 & 57 \\
\hline
\end{tabular}

**. Correlation is significant at the 0.01 level (2-tailed).

*. Correlation is significant at the 0.05 level (2-tailed).

PS: X1: Issue price, X2: P/E ratio, X3: Number of items of evaluation index, $\mathrm{X} 4$ : The average proportion of authorization, $\mathrm{X} 5: \ln ($ total assets). That Pearson Correlation Coefficient is greater than 0 means positive correlation between the two, less than 0 means negative correlation between the two.

We can draw the following conclusion:

(1) There is positive correlation between issue price and $\mathrm{P} / \mathrm{E}$ ratio. The absolute value of Pearson coefficient is between 0.5 and 0.8 , so it's moderate correlation.

(2) Items of evaluation index, average proportion of authorization and $\ln$ (total assets) three variates have negative correlation with issue price, the absolute value of Pearson coefficient is less than 0.3 , which means weak correlation, namely no correlation.

(3) Items of evaluation index and average proportion of authorization two variates have negative correlation with $\mathrm{P} / \mathrm{E}$ ratio, the absolute value of Pearson coefficient is less than 0.3, which means weak correlation, namely no correlation.

(4) $\mathrm{P} / \mathrm{E}$ ratio has negative correlation with $\ln$ (total assets), the absolute value of Pearson coefficient is between 0.3 and 0.5 , which means low correlation.

(5) Average proportion of authorization and $\ln$ (total assets) two variates have positive correlation with items of evaluation index, the absolute value of Pearson coefficient is less than 0.3, which means weak correlation, namely no correlation.

(6) Average proportion of authorization has positive correlation with $\ln$ (total assets), the absolute value of Pearson coefficient is less than 0.3 , which means weak correlation, namely no correlation.

\subsection{The Empirical Research}

We can see from the Table, the $\mathrm{P}$ value of constant term $\mathrm{C}(1)$ is greater than 0.1 , it's not significant, thus, we deleted constant term and then made regression again. Here is the result:
Table 8. Preliminary results of regression analysis.

\begin{tabular}{l|l|l|l|l}
\hline & Coefficient & $\begin{array}{l}\text { Std. } \\
\text { Error }\end{array}$ & z-Statistic & Prob. \\
\hline C(1) & 0.098888 & 3.201949 & 0.030884 & 0.9754 \\
C(2) & 0.079146 & 0.043911 & 1.802393 & 0.0715 \\
C(3) & 0.023409 & 0.020146 & 1.161966 & 0.2452 \\
C(4) & -2.236969 & 0.944963 & -2.367257 & 0.0179 \\
C(5) & -16.93222 & 8.596700 & -1.969619 & 0.0489 \\
$\begin{array}{l}\text { C(6) } \\
\text { McFadden }\end{array}$ & 0.272196 & 0.194165 & 1.401878 & 0.1610 \\
$\begin{array}{l}\text { R-squared } \\
\text { S.D. dependent } \\
\text { var }\end{array}$ & 0.354595 & Mean dependent var & 0.614035 \\
$\begin{array}{l}\text { Akaike info } \\
\text { criterion }\end{array}$ & 0.491150 & S.E. of regression & 0.405128 \\
$\begin{array}{l}\text { Schwarz } \\
\text { criterion }\end{array}$ & 1.071379 & Sum squared resid & 8.370574 \\
$\begin{array}{l}\text { Hannan-Quinn } \\
\text { criter. }\end{array}$ & 1.286437 & Log likelihood & -24.53430 \\
$\begin{array}{l}\text { LR statistic } \\
\text { Prob (LR } \\
\text { statistic) }\end{array}$ & 1.154958 & Restr. log likelihood & -38.01381 \\
$\begin{array}{l}\text { Obs with Dep=0 } \\
\text { Obs with Dep=1 }\end{array}$ & 26.95900 & Avg. log likelihood & -0.430426 \\
\hline
\end{tabular}

Table 9. Results of regression analysis.

\begin{tabular}{lll|l|l}
\hline & Coefficient & Std. Error & t-Statistic & Prob. \\
\hline $\mathrm{C}(2)$ & 0.007204 & 0.003576 & 2.014582 & 0.0491 \\
$\mathrm{C}(3)$ & 0.005010 & 0.003152 & 1.589643 & 0.1180 \\
$\mathrm{C}(4)$ & -0.232847 & 0.100140 & -2.325217 & 0.0240 \\
$\mathrm{C}(5)$ & -2.423485 & 0.972436 & -2.492180 & 0.0159 \\
$\mathrm{C}(6)$ & 0.065279 & 0.015992 & 4.081874 & 0.0002 \\
$\begin{array}{l}\text { R-squared } \\
\text { Adjusted }\end{array}$ & 0.335480 & Mean dependent var & 0.614035 \\
$\begin{array}{l}\text { R-squared } \\
\text { S.E. of }\end{array}$ & 0.284363 & S.D. dependent var & 0.491150 \\
$\begin{array}{l}\text { regression } \\
\text { Sum squared }\end{array}$ & 0.415490 & Akaike info criterion & 1.164914 \\
resid & 8.976851 & Schwarz criterion & 1.344129 \\
$\begin{array}{l}\text { Log likelihood } \\
\begin{array}{l}\text { Durbin-Watso } \\
\text { n stat }\end{array}\end{array}$ & -28.20004 & Hannan-Quinn criter. & 1.234563 \\
\hline
\end{tabular}

Results of Logit regression showed that the changing direction of the independent variable and the dependent variable, when the coefficient is negative, the independent variable and the dependent variable have negative correlation, differently, there is positive correlation between the independent variable and the dependent variable.

We can draw the conclusion from Table 9:

(1) The issue price of coefficient $\mathrm{C}$ (2) is positive and $\mathrm{P}$ value is less than $5 \%$, it means that the coefficient in the $5 \%$ significance level significantly, and incentive objects are positively related to turnover, indicating that the higher issuing price of listed companies, incentive objects turnover probability is low, activating constraint effect of the equity incentive is better, so that shares of listed companies and the issue price of equity incentive of activating constraint effect have negatively correlated. As a result, the state and the listing Corporation can improve the IPO inquiry system, so to improve the positive constraint effect of the stock incentive. 
Because of the economic interests of the people, when the listing Corporation's stock issue price is higher, the more likely to be incentive to leave the cash, so managers can also be extended by the executives to hold the limit of the sale of shares and the ban period to reduce the turnover rate of incentive executives, to protect the positive constraint effect of equity incentive.

(2) The distribution coefficient of $\mathrm{C}$ price earnings ratio (3) is positive, but the $\mathrm{P}$ value is 0.1180 , slightly more than $10 \%$, so the coefficient is not significant.

(3) Equity incentive coefficient of performance evaluation items $\mathrm{C}$ (4) is negative and $\mathrm{P}$ value is less than $5 \%$, it is significance level significantly in $5 \%$, and incentive objects turnover is negatively related to that equity incentive in listed companies performance evaluation index system of the more items, incentive objects turnover probability is low, namely equity incentive of active constraint effect can be better, the equity incentive performance evaluation index of the items and equity incentive of active constraint effect showed a positive correlation. More number of equity incentive performance evaluation index, the positive effects of the listing Corporation's equity incentive constraint is more obvious. Therefore, in order to change the current situation from the positive restraint effect of many equity incentive plan and unsatisfactory, the listing Corporation can improve the performance evaluation index system so to improve the positive restraint effect of stock incentive through improving the equity incentive plan.

(4) The mean of C (5) is negative, and the average number of shares in the listing Corporation is negatively related to the proportion of the total share capital, the ratio of the incentive object is higher, and the lower probability of the incentive, the incentive to retain the talent, which is a positive correlation between the stock incentive plan and the significant level of 5\%. Therefore, the listing Corporation can improve the equity incentive plan, equity incentive plan to increase the number of shares granted to the incentive in the development, so it is better to achieve the positive constraint effect of equity incentive.

\section{The Countermeasures to the Listed Companies' Active Constraint of Equity Incentive}

\subsection{Improve the New Share Pricing System}

Based on the empirical research of the last chapter, study group have proved the effect of the stock price of the Listing Corporation on the positive restriction effect of the stock option incentive, the issue price is restricted by the stock option incentive scheme. In recent years, China has begun to explore and implement the inquiry system of new shares. However, the inquiry system of China has not completely realized the market. China's IPO inquiry system provides the basis for the IPO price is a preliminary inquiry to some institutional investors to get results, but the issue price is likely to reflect the real value and performance of the listing Corporation, because the sponsor is likely to control the price of new shares issued to choose a number of institutional investors that as an inquiry object, and these are subject to the issuer and the sponsor of the issuer unilateral choice. Therefore, the positive restraint effect of stock option is likely to be weakened.

To solve this problem, it can improve from the following two aspects: first, increasing the price of new shares issued to determine the factors can be a moderate consideration of other investors, especially small and medium investors' inquiry. The determination of the issue price is not a result that the inquiry of the institutional investors. In China's current securities market, small investors still occupy a large proportion, so the issue price is not only a matter of institutional investors, small investors can also be involved, so as to stop the small investors can only passively accept the pricing results of this unfair phenomenon. Second, the establishment of institutional investors in the assessment system, through a series of assessment indicators to reduce agency's choice of institutional investors as a means of inquiry, such as institutional investors should have a certain professional ability, and has better integrity of history, financial strength and operational norms. At the same time, it can also use newspapers, networks and other channels to publish the results of the assessment, to meet the conditions, qualified institutional investors in the bid for some of the incentives, and to impose penalties on institutional investors that do not meet the conditions.

\subsection{To Design an Effective Equity Incentive Plan}

The effective design of the equity incentive scheme is the basis of the full play. We should improve the equity incentive plan from the following two points: first, the performance evaluation index system should be diversified and long-term. According to the empirical research of the last chapter, the performance evaluation index system is more diverse, more comprehensive; the positive restraint effect of stock incentive is more significant. Limited to China's securities capital market is not mature, the listing Corporation's performance evaluation index system is the main application of the financial index system, and scientific and reasonable assessment system should be absolute and relative indicators, both vertical and horizontal comparison, non financial indicators and financial indicators. With the continuous improvement of the securities capital market, consider the use of the $\mathrm{Q}$ value method, the economic value added (EVA) method and other direct and stock price correlation method as the performance assessment method, increase the assessment of diversity and comprehensive, so as to ensure the positive constraint effect of the stock incentive effect. Second: to increase the number of equity incentives granted to the incentive object, the empirical study of the last chapter shows that the lower the number of equity incentives can weaken the positive restraint effect, that's the reason of listing Corporation can increase the number of shares granted in the 
incentive plan, that it can increase the incentive, the incentive to achieve the positive constraint effect.

\subsection{Improve Relevant Laws and Regulations}

Although there are many listing Corporation launched the equity incentive plan. But it is not much effective implementation of the positive, the positive effect of the stock incentive is not fully played. Chinese law is also one of the important factors causing this problem.

For this problem, study group should combine the specific situation of China's capital market and the relevant rules of the company law and securities law, and the conflict between the relevant laws and regulations, which should formulate a series of laws and regulations, which can provide good legal protection for the equity incentive mechanism. For example, one: to extend the ban on the sale of shares held by senior executives; reduce the rate of incentive to the object of the resignation rate, to protect the positive effect of the incentive stock. Because if the time limit for the sale of shares period was extended, the incentive executives even if you want to resign, you must also wait until the expiration of the lifting the ban can be carried out. So the departure of the period of time for the extension banned, to stick to their posts, not to resign to provide some of the incentives to reward, the probability of the object will be encouraged to resign will be reduced, the positive effect will be improved equity incentive Two: the introduction of a unified standard of accounting confirmation rules. Otherwise, the different ways of dealing with the company are not the same, which may cause the financial index of the non - ratio, the impact of equity incentive performance assessment of the fair, and weaken the role of equity incentive. This will also bring risks to the future of the company's internal management and external supervision.

\section{Conclusion and Prospect}

\subsection{Summarization}

Equity incentive is an important means of incentive, although the listing Corporation has introduced a variety of equity incentive form and program, but the real implementation of the real is not much, the positive effect of the stock incentive has not been fully played.

Through the analysis of the current situation of the positive restraint effect of the equity incentive of the listing Corporation and the empirical research, the following conclusions are drawn:

First, the stock price of the listing Corporation and the positive restriction effect of the equity incentive show a negative correlation. The issue price of the company's stock is higher, which means that the company's stock has a higher valuation, that leads to the value of the equity held by the incentive object, because the people economic interests, the incentive object may choose to leave the cash and to get the stock price over expansion. Therefore, the higher stock issue price, the higher probability of the object of the incentive to the object, the positive effect of equity incentive on the worse. So the stock price and stock incentive of the positive constraints effect is positively related.

Second, the effect of the performance evaluation index and the number of active constraints of equity incentive equity incentive has positive correlation. The performance evaluation index system of unitary equity incentive plans are often not able to fully and correctly evaluate the incentive objects made contribution to the company, so it is impossible to be incentive target incentive to play the role, the positive effects of the equity incentive plan of the natural constraints are not guaranteed, the performance evaluation index system can fully diversified equity incentive a fair assessment of each was encouraged by the development of the company to do object to ensure fairness, equity incentive plan, incentive target has been properly recognized and some of the rewards, they are willing to stay for the company to continue working, incentive target was to reduce the turnover rate, the positive effects of equity incentive constraint that it will improve. The positive effect of the performance evaluation index and the number of constraints of equity incentive equity incentive has positive correlation.

Third, the average number of shares held by the incentive object is positively related to equity incentive, equity incentive plan to grant incentive to the object, the company's loss to the manager's share is small, the impact of small, can not have the positive effect of the stock incentive, so that the proportion of the total share capital and share equity incentive, the positive constraint effect is positively related.

In view of the current situation of the positive restraint effect of stock incentive, the paper puts forward some improvement measures:

First, improve the inquiry system, the price of new shares issued to determine the factors, the small and medium investors to consider the scope of the inquiry. The establishment of institutional investors is in the assessment system, to ensure the impartiality and professionalism of institutional investors.

Second, how to design effective equity incentive plan, increase equity incentive performance appraisal index system of the number of items, so that a more diversified and comprehensive performance evaluation index system. The increase in the number of equity incentives granted to the object of interest, so that it is more attractive to the incentive.

Third, improve the relevant laws and regulations and regulations, and to extend the period of limited sale of shares held by senior executives to reduce the turnover rate of incentive executives. The introduction of unified standards of accounting rules to determine the equity incentive performance assessment of the fair.

\subsection{The Innovation and Limitations of This Paper}

(a) The innovation of the article

This paper first analyzes the status quo and influence factors of the positive restraint effect of stock incentive, which mainly considers the impact of the issue price, 
earnings ratio, stock price earnings ratio, stock price earnings ratio, stock price earnings ratio, stock index system, and the average number of stock incentive. The reason of the positive restraint effect of the equity incentive of the listing Corporation can not be reached.

(b) The limitations of the article

Because of its ability to limit and time to rush, the article also has many deficiencies, in general, the following main points:

First, the empirical study of this paper selects 57 listing Corporation's equity incentive plan, the selection of the sample is limited, the data is not sufficient; the results may have some bias.

Second, this paper studies the positive restraint effect of equity incentive, which is mainly from the company and equity incentive plan level, and not considers other factors, such as the choice of incentive object, and so on, which will make the research conclusions deviation.

Third, in this paper, the influence factors of the positive restraint effect of equity incentive are analyzed by using descriptive analysis and Logit regression analysis.

\subsection{The Prospect of the Research}

Because of the short time and limited space, this paper focuses on the positive restriction effect of the stock incentive of the listing Corporation, including the main board, small board and gem, and has not studied the characteristics of the positive restraint effect of different sectors of the listing Corporation. Future research can make a comparative study of the positive constraints of the gem, small board and the main board of equity incentive, and explore their own situation and the reasons behind.

\section{References}

[1] $\mathrm{Wu}$ Shuchun, Zhu Xu. Elementary Analysis of Equity Incentive of Listed Companies [J]. China Collective Economy, 2012, (1): 106-107.

[2] Lin Danfeng. Analysis and Improvement Measures of Equity Incentive's Status Quo of Chinese SMEs Board and GEM Board [J]. Modern Commerce, 2012, (1): 146.

[3] Peng Jianqiang. Elementary Analysis of Equity Incentive of Listed Companies [J]. Market Forum, 2011, (8):150-151.

[4] Wei Gang. Incentive to Senior Management and Performance of Listed Companies [J]. Economic Research, 2000, (3): 32-39.

[5] Song Zengji, Zhang Zongyi. Empirical Research of Shares Structure of Listed Companies and Companies' Performance [J]. Quantitative \& Technical Economics, 2003, (1): 128-132.

[6] Gu Bin, Zhou Liye. The Research of Implementation Effect of Chinese Listed Companies' Equity Incentive [J]. Accounting Research, 2007, (2): 79-84.

[7] Wu Shukun. The Research of U-relationship of Shares Structure and Performance-Empirical Research of Listed
Companies from 1997 2000 [J]. China Industrial Economics, 2002, (1): 80-87.

[8] Song Zengji, Zhang Zongyi, Zhu Jian. The Research of Influence of Operators' Equity Incentives in Listed Companies [J]. Management Review, 2005, (3): 3-8.

[9] Chen Yong, Liao Guanming, Wng Ting. The Empirical Research of China's Equity Incentives in Listed Companies [J]. Management World, 2005, (2): 158-159.

[10] Yuan Yan, Yu Haiying. The Research of Relationship of Equity Incentive and Performance Based on Listed Companies' Practical Data [J]. Contemporary Economics, 2007, (6): 12-13.

[11] Li Yuxiang, Liu Dongxin. Elementary Analysis of Status Quo of Listed Companies' Equity Incentive [J]. Accounting Weft, 2009, (5): 98-100.

[12] Song Zengji, Zhang Zongyi. Empirical Research of Shares hold by Managers in Listed Companies and the Performance [J]. Journal of Chongqing University (Social Science Edition), 2008, (6): 1-2.

[13] Cheng Longyun, Yue Chunmiao. The Empirical Research of Equity Incentive's Performance of Senior Management Levels in Listed Companies [J].Research on Economics and Management, 2008, (5): 5-6.

[14] Zhang Liang, Mao Daowei, Yan Lei. The Research of Influencing Factors of Equity Incentive's Intensity and Structure in Listed Companies [J].Social Science Research, 2010, (4): 48-53.

[15] Wang Qiuxia, Chen Xiaoyi. The Empirical Research of Economic Performance of Chinese Companies' Equity Incentive [J]. Market Forum, 2007, (8): 56-58.

[16] Liu Hua, Zhen Jun. Equity Incentive and Performance of High-tech Listed Companies-Based on the Angle of Independent Innovations [J]. Friends of Accounting, 2010, (12): 67-70.

[17] Zhou Jianbo, Sun Jusheng. The Research of Governance Effect of Operators' Equity Incentives-Experience and Evidence comes from Chinese Listed Companies [J]. Economic Research, 2003, (5): 74-82.

[18] Yang Hua, Chen Xiaosheng. Theory, Regulation and Practice of Equity Incentive [M].Beijing: China Economic Publishing House, 2008, 3-50.

[19] Chen Qingtai, Wu Jinglian. The Empirical Research of Stock Option [M]. Beijing: China Financial and Economic Publishing House, 2001, 271-275.

[20] Ye Yonggang, Lai Xiaoyan, Huang Zhuoli. Stock Option [M].Wuhan, Hubei Province: Wuhan University Press, 2000, 1-3.

[21] Jensen, M. and Meckling, W. Theory of Firm: Managerial Behavior, Agency Costs and Ownership Structure [J]. Journal of Financial Economics, 1976, (3): 305-360.

[22] Demsetz HK. The Structure of Corporate Ownership: Causes and Consequences [J]. Journal of Political Economy, 1985, (6): 1155-1177.

[23] Mork. R., Andrci Shlerfer, and Rober W. Vishny. Management Ownership and Market Valuation: An Empirical Analysis [J]. Journal of Financial Economics, 1988, 20(1): 293-317. 
[24] KoIe S R. Measuring managerial eguity ownership: A comparison of sources of ownership data [J]. Journal of Corporate Finance, 1995, (1): 413-435.

[25] Short H, Keasey K. ManageriaI ownership and the performance of firms: Evidence from the UK [J]. JournaI of Corporate Finance, 1999, (5): 79 - 101.

[26] Murphy, Kevin J.. Performance Pay and Top-Management Incentives [J]. Journal of Political Economy, 1990, (1): 37 - 49. 